Jurnal Pengabdian kepada Masyarakat

Vol.5, No.1, April 2019, Hal 17-35

(Indonesian Journal of Community Engagement)

DOI: http://doi.org/10.22146/jpkm.32111

\title{
SOSIALISASI BUDIDAYA KURMA DAN KONSEP GREEN CONSTITUTION
}

\author{
Hayatul Ismi ${ }^{1}$, Yeni Kusumawaty*2, Evi Deliana ${ }^{1}$, Ulfia Hasanah ${ }^{1}$, Dessy Artina $^{1}$, Erdiansyah \\ Erdiansyah $^{1}$, dan Fenny Trisnawati ${ }^{1}$ \\ ${ }^{1}$ Fakultas Hukum, Universitas Riau, Jl. Pattimura No.9, Cinta Raja, Sail, Kota Pekanbaru, Riau 28127, \\ Indonesia. \\ ${ }^{2}$ Departemen Agribisnis, Fakultas Pertanian, Universitas Riau, Simpang Baru, Tampan, Kota Pekanbaru, \\ Riau 28292, Indonesia. \\ *yeni.kusumawaty@unri.ac.id
}

Submisi: 08 Januari 2018; Penerimaan: 05 April 2019

Kata Kunci: desa Abstrak Kabupaten Rokan Hulu terkenal akan wisata religinya yaitu masjid wisata religi; $\quad$ Islamic Center Madani yang dikunjungi oleh ribuan pengunjung dari berbagai konstitusi hijau; daerah setiap minggunya. Sebagai penunjang ciri khas daerah wisata religi, pihak kurma.

Keywords: religious tourism village; green constitution; dates. manajemen merencanakan pembudidayaan tanaman kurma yang diinspirasi oleh Kitab Suci al-Qur'an untuk meningkatkan pendapatan dan kesejahteraan masyarakat Desa Babussalam. Terkait dengan tanaman kurma yang relatif baru di Indonesia, diperlukan sosialisasi tentang potensi tamanan kurma dan konsep peraturan desa yang terkait dengan konsep green constitution. Sosialisasi dilakukan kepada perangkat Desa Babussalam Kecamatan Rambah Kabupaten Rokan Hulu untuk merintis program budidaya tanaman kurma melalui peraturan desa. Diharapkan dapat meningkatkan taraf hidup masyarakat desa Babussalam sekaligus sebagai desa percontohan budidaya kurma. Indikator kegiatan ini yaitu terwujudnya peningkatan pengetahuan dan motivasi, tingkat partisipasi, kesesuaian materi, dan faktor dampak implementasi kegiatan lebih lanjut. Berdasarkan indicator tersebut, Desa Babussalam dinilai berhasil dan dapat meningkatkan pengetahuan, motivasi dan kesiapan perangkat Desa dalam mempersiapkan peraturan desa sebagai implementasi green constitutiondalam budidaya tanaman kurma sebagai trademark kabupaten Rokan Hulu sebagai daerah tujuan wisata religi.

Abstract Rokan Hulu Regency is famous for its religious tourism, namely the Islamic Center Madani mosque which is visited by thousands of visitors from various regions every week. As a support for the characteristics of religious tourism areas, the management plans to cultivate date palms inspired by the Holy Qur'an to increase the income and welfare of the people of Babussalam Village. Related to the relatively new date palm plants in Indonesia, socialization of the potential of date palms and the concept of village regulations is needed relating to the concept of green constitution. The socialization was carried out to Babussalam Village officials in Rambah Sub-District, Rokan Hulu District to initiate a program to cultivate date palms through village regulations. It is hoped that it can improve the standard of living of the people of Babussalam village as well as a pilot village for date palm cultivation. Indicators of this activity are the realization of an increase in knowledge and motivation, the level of participation, the suitability of the material, and the impact factors for the implementation of further activities. 
Based on these indicators, Babussalam Village is considered successful and can increase the knowledge, motivation, and readiness of the Village apparatus in preparing village regulations as the implementation of the green constitution in the cultivation of date palms as a trademark of Rokan Hulu district as a religious tourism destination.

\section{PENDAHULUAN}

Sebagian besar rakyat hidup pada sektor pertanian dan sektor ini masih memberikan kontribusi yang besar pada perekonomian Indonesia. Menurut Wardhono (2008), paradigma baru kebijakan pertanian adalah konsep pengembangan potensi sumber daya yang bersifat lokal, terpadu, terkoordinasi dan berwawasan agribisnis, yang membutuhkan strategi untuk meningkatkan daya saing. Sejalan dengan konsep pengembangan sektor pertanian, sub sektor tanaman pangan memegang peranan penting dalam menyediakan pangan bagi masyarakat dan memberikan kontribusi tinggi terhadap Gross Produk Nasional (GNP), dan membuka lapangan kerja pedesaan. Pembangunan Sub Sektor Perkebunan mempunyai peran yang cukup penting dalam pembangunan di Kabupaten Rokan Hulu. Hal ini disebabkan karena sebagian besar penduduk mempunyai mata pencaharian sebagai petani pekebun. Kondisi lahan yang sebagian besar berupa dataran rendah cocok untuk perkebunan (Isyandi \& Indarti, 2008). Dengan harga karet yang cenderung menurun sepuluh tahun terakhir, kondisi topografi dan ketersediaan di Desa Babussalam cukup memungkinkan untuk pengembangan komoditi kurma.

Pemberdayaan ekonomi rakyat juga berarti membangun ekonomi pertanian dengan lebih baik. Dalam upaya pemberdayaan ekonomi masyarakat pedesaan, Bupati Rokan Hulu periode Tahun 2011-2016, Drs. H. Achmad, M.Si., pernah mencanangkan program Budidaya Tanaman Kurma, namun karena terjadinya peralihan kepemimpinan hal tersebut belum terealisasi. Kepala Desa terpilih Desa Babussalam Kabupaten Rokan 
Hulu, Basron, mengatakan bahwa salah satu cara yang ditempuh dalam memacu pembangunan desa dalam rangka meningkatkan kualitas ekonomi masyarakat desa dapat dilakukan melalui cara budidaya tanaman kurma, salah satu akibat merosotnya nilai jual sawit dan karet beberapa waktu ini, hal ini dilakukan sejalan dengan apa yang telah dicanangkan oleh Bupati sebelumnya, Kepala Desa optimis tanaman kurma akan menjadi alternatif yang menjanjikan sebagai pengganti tanaman kelapa sawit dan karet yang harganya cenderung menurun. Menurut Isyandi \& Indarti (2008), kondisi pertanian saat ini masih mengandalkan kelapa sawit dan karet dengan luas areal perkebunan kelapa sawit mencapai 68,93 persen dari total luas lahan perkebunan, tanaman karet sebesar 29,39 persen, tanaman kelapa 0,81 persen dan tanaman lainnya 0,87 persen.

Lebih lanjut diungkapkan oleh Basri (2007) di dalam Syahza (2012), pemberdayaan masyarakat pedesaan juga harus mampu memberikan perlindungan yang jelas terhadap masyarakat. Upaya perlindungan dimaksudkan untuk mencegah terjadinya persaingan yang tidak seimbang akibat berlakunya mekanisme pasar dan eksploitasi yang kuat terhadap yang lemah. Dalam hal ini, tampaknya sulit diterapkan mekanisme pasar. Masyarakat desa jelas akan kalah bersaing. Mereka tidak punya apaapa selain tenaga-tenaga yang pada umumnya kurang terlatih. Pembangunan pedesaan yang efektif tidak saja akan mewujudkan pembagian kekayaan dan pendapatan yang merata, tetapi juga merupakan sumber pertumbuhan ekonomi yang pesat karena berhasil mendorong berkembangnya industrialisasi. Dengan kata lain, kesejahteraan masyarakat akan meningkat kalau kesejahteraan sudah tercapai, pasti kepentingan lain akan lebih mudah lagi dicapai. 
Sejumlah konsep dalam berbagai bidang yang terkait dengan kesadaran lingkungan hidup diantaranya adalah green economy, green technology, green entrepreneurship, green innovation, dan green marketing. Wahyudin (2016) memaparkan bahwa salah satu upaya menyelaraskan antara kebutuhan manusia akan pertumbuhan ekonomi sekaligus melestarikan ekosistem adalah konsep pertumbuhan hijau (green growth). Pertumbuhan ekonomi hijau adalah konsep pertumbuhan yang memprioritaskan faktor kualitas dan kuantitas ekosistem dan mengurangi kesenjangan sosial masyarakat dalam mengejar pertumbuhan ekonomi. Munculnya konsep pertumbuhan hijau ini didorong juga oleh kekhawatiran dunia terhadap dampak pertumbuhan ekonomi konvensional terhadap ekosistem, dengan banyaknya eksploitasi sumber daya alam dan meningkatnya kesenjangan sosial.

Salah satu terminologi dan konsep hjau yang kini tampaknya masih belum terdiseminasi dan dipahami secara luas, yaitu green constitution (konstitusi hijau). Terminologi dan konsep green constitution merupakan fenomena baru di kalangan praktisi dan akademidi yang menggeluti tentang isu lingkungan, termasuk di kalangan para ahli hukum dan konstitusi. Adalah Profesor Jimly Asshiddiqie yang mencoba mengakrabkan publik Indonesia dengan terminologi dan konsep green constitution tersebut, terutama melalui bukunya yang berjudul Green Constitution: Nuansa Hijau Undang-Undang Dasar Negara Republik Indonesia Tahun 1945 (Asshidiqie, 2010).

Pada prinsipnya, dalam konteks Indonesia, green constitution dan ecocracy tercermin dalam gagasan tentang kekuasaan dan hak asasi manusia serta konsep demokrasi ekonomi sebagaimana ditegaskan oleh Undang-Undang Dasar Negara Republik Indonesia Tahun 1945. Pasal 28H Ayat (1) dan pasal 33 Ayat (4) UndangUndang Dasar Tahun 1945 memberikan basis konstitusional bagi green constitution. 
Dengan demikian, norma perlindungan lingkungan hidup di Indonesia sebetulnya kini telah memiliki pijakan yang semakin kuat. Namun, masih belum banyak pembuat kebijakan publik maupun masyarakat luas di Tanah Air yang mengetahui dan memahami tentang hal yang penting ini. Itulah sebabnya diperlukan program untuk menyebarluaskan pengetahuan pemahaman tentang green constitution dan ecocracy tersebut.

Pentingnya prinsip pembangunan berkelanjutan yang berwawasan lingkungan dan perlindungan terhadap lingkungan hidup menjadi memiliki pijakan yang kuat dalam peraturan perundang-undangan. Atas dasar itu, green constitution kemudian mengintroduksi terminologi dan konsep yang disebut dengan ekokrasi (ecocracy) yang menekankan pentingnya kedaulatan lingkungan. Dalam konteks Indonesia, green constitution dan ecocracy tercermin dalam gagasan tentang kekuasaan dan hak asasi manusia serta konsep demokrasi ekonomi sebagaimana ditegaskan oleh UndangUndang Dasar Negara Republik Indonesia Tahun 1945. Pasal 28H Ayat (1) dan pasal 33 Ayat (4) Undang-Undang Dasar Tahun 1945 memberikan basis konstitusional bagi green constitution. Dengan demikian, norma perlindungan lingkungan hidup di Indonesia sebetulnya kini telah memiliki pijakan yang semakin kuat. Namun, masih belum banyak pembuat kebijakan publik maupun masyarakat luas di Tanah Air yang mengetahui dan memahami tentang hal yang penting ini. Itulah sebabnya diperlukan program untuk menyebarluaskan pengetahuan pemahaman tentang green constitution dan ecocracy tersebut. Program green constitution ini dirancang untuk memenuhi kebutuhan tersebut.

Terkait dengan kebijakan ekonomi dan lingkungan, ketentuan Pasal 33 dan Pasal 34 yang sebelumnya hanya berisi empat butir ketentuan dengan rumusan yang samar- 
samar dan bersifat 'multi-interpretasi' sejak Perubahan Keempat 2002, Pasal 33 itu dilengkapi menjadi terdiri atas 5 ayat, dan Pasal 34 menjadi terdiri atas 4 ayat, sehingga seluruhnya menjadi 9 butir ketentuan. Kesembilan norma konstitusi tersebut ditambah lagi dengan ketentuan yang terkait dengan hak asasi manusia Pasal $28 \mathrm{H}$ ayat (1) menjadi sepuluh norma dasar yang menyebabkan UUD 1945 benar-benar harus dipandang sebagai konstitusi perekonomian, di samping konstitusi politik. Karena itu, UUD 1945 dewasa ini telah makin tegas mempermaklumkan diri sebagai konstitusi ekonomi (economic constitution, the constitution of economic policy), di samping sebagai konstitusi politik (political constitution). Penempatan konstitusional perekonomian sebagai norma dalam konstitusi memiliki kedudukan yang dapat memaksa untuk dipakai sebagai standar rujukan dalam semua kebijakan ekonomi. Dengan perkataan lain, ekonomi memperhitungkan, politik memutuskan, tetapi hukum yang akhirnya menentukan.

Kebijakan ekonomi Pemerintah Desa Babussalam dalam penyediaan kurang lebih 1 hektar sebagai lahan budidaya tanaman kurma tersebut belum dibarengi dengan acuan, pedoman ataupun pola pengelolaan tanaman kurma oleh masyarakat, sehingga sangat dibutuhkan pembinaan melalui pengabdian masyarakat. Kegiatan ini melakukan pembinaan terkait dengan pengelolaan tanaman kurma, dan aturan desa atau perdes yang akan memproteksi, sehingga tanaman kurma tersebut dapat dikelola sesuai dengan harapan, dapat meningkatkan taraf hidup masyarakat desa dan menjadi desa percontohan dalam budidaya tanaman kurma. Menurut Yusa \& Hermanto (2018), konsep Green Constitution di Indonesia dimaknai sebagai konstitutionalisasi norma hukum lingkungan sebagaimana diatur dan terimplementasi dalam ketentuan Pasal $28 \mathrm{H}$ ayat (1) dan Pasal 33 ayat (4) UUD NRI Tahun 1945 serta konsiderans menimbang 
huruf a, b, f, Pasal 1 angka (2), Pasal 44, Penjelasan Bagian I. Umum angka (1) dan (5) Undang-Undang Nomor 32 Tahun 2009. Namun demikian, Green Constitution belum tercermin secara holistik, terbatas pada indikator masyarakat, namun belum didukung indikator hukum dan indikator pelaksana praktik hukum. Sejalan dengan kondisi yang terkait dengan konsep konstitusi hijau yang relatif baru di Indonesia, kurangnya diseminasi, dan ditambah dengan kebutuhan untuk melindungi masyarakat luas dari penguasaan sumber daya termasuk lahan oleh pihak swasta yang bermodal besar, dibutuhkan sosialisasi tentang konstitusi hijau dalam konteks peraturan desa di Desa Babussalam Kabupaten Rokan Hulu.

\section{PERMASALAHAN}

Kabupaten Rokan Hulu memiliki potensi yang besar di bidang perkebunan diantaranya adalah perkebunan karet dan kelapa sawit. Menurut Wahyuni et al. (2013), perkebunan karet merupakan salah satu sumber ekonomi penduduk di Kabupaten Rokan hulu diantaranya di Kecamatan Rambah Hilir dengan luas area 10,602 hektar dengan produksi sebesar 3,373.97 ton yang menjadi sumber penghidupan 2,478 kepala keluarga. Selain potensi perkebunan karet, Kabupaten Rokan Hulu merupakan salah satu kabupaten dengan potensi perkebunan kelapa sawit yang luas di Provinsi Riau. Pada tahun 2010, Kabupaten Rokan Hulu memiliki luas perkebunan kelapa sawit seluas 162.072,08 hektar. Kontribusi perkebunan kelapa sawit terhadap perekonomian kabupaten Rokan Hulu cukup besar baik terhadap pengembangan wilayah, Produk Domestik Regional Bruto (PDRB) maupun terhadap pembukaan lapangan kerja. Pada tahun 2010, kesempatan kerja yang terbuka dalam kegiatan perkebunan kelapa sawit secara langsung di Kabupaten Rokan Hulu adalah sebanyak 32.414 orang yang 
mencakup semua pekerjaan yang ada di sektor perkebunan kelapa sawit (Kadir dan Syapsan, 2012).

Hanya saja dalam perkembangannya industri kelapa sawit pada skala besar telah menimbulkan dampak secara ekologi. Menurut Septiawan et al. (2014), telah timbul sejumlah tudingan dari aktivis lingkungan yang mengopinikan industri kelapa sawit menyebabkan dampak negatif terhadap lingkungan yang merugikan dan akan mempengaruhi pengembangan industri kelapa sawit di masa mendatang. Diantara dampak negatif yang dikaitkan dengan kelapa sawit adalah dampak kerusakan lingkungan, emisi gas rumah kaca, hingga pemicu deforestasi. Terkait dengan permasalahan lingkungan yang terutama ditimbulkan oleh perkebunan kelapa sawit skala besar, dibutuhkan pertanian yang berkelanjutan tanpa merusak lingkungan. Kata 'berkelanjutan' yang dimuat dalam Pasal 33 ayat (4) UUD 1945 sebenarnya berkaitan dengan konsep sustainable development (pembangunan berkelanjutan). Pembangunan berkelanjutan merupakan salah satu perwujudan dari wawasan lingkungan yang dimaksud dalam UUD 1945 tersebut. Sebaliknya, prinsip pembangunan yang berkelanjutan juga harus diterapkan dalam kebijakan pembangunan yang berwawasan lingkungan. Tidak ada pembangunan berkelanjutan tanpa lingkungan hidup sebagai unsur utamanya, dan tidak ada wawasan lingkungan tanpa pembangunan berkelanjutan.

Pembangunan berkelanjutan (sustainable development) sebenarnya baru mulai diperkenalkan kembali dengan diterbitkannya kembali buku Silent Spring karangan Carson (2002). Dalam konsep pembangunan berkelanjutan tersebut, proses pembangunan atau perkembangan (development) diharapkan dapat memenuhi kebutuhan masa sekarang tanpa membahayakan kemampuan generasi yang akan datang untuk memenuhi kebutuhannya dalam memanfaatkan potensi sumber daya alam untuk 
kehidupan. Terkait dengan dampak lingkungan perkebunan yang saat ini eksis di Kabupaten Rokan Hulu, diperlukan alternatif produk pertanian potensial yang sejalan dengan konsep konstitusi hijau. Potensi yang dapat dikembangkan di Kabupaten Rokan Hulu adalah potensi bidang pariswisata khususnya wisata alam dan religi. Rokan Hulu saat ini sudah cukup dikenal dengan wisata religinya dengan objek wisata masjid Islamic Center Madani yang setiap minggu dikunjungi oleh ribuan pengunjung dari berbagai daerah, ini juga merupakan situasi yang dapat dianalisis, karena dengan demikian menunjukkan tingginya wisata yang datang ke Rokan Hulu, hal ini menjadi pemicu juga bagi kepala desa terpilih desa Babussalam untuk membudidayakan kurma sebagai pengembangan wisata religi Islamic center tersebut. Kurma dapat diolah menjadi berbagai makanan yang dapat dijadikan oeh-oleh bagi pengunjung wisata di Rokan Hulu. Ini adalah peluang yang menjanjikan bagi masyarakat desa babussalam jika bisa dikelola dengan baik dan diproteksi dengan peraturan desa yang baik pula.

Pengembangan kedepan untuk masyarakat diharapkan menjadi penghasilan yang menjanjikan bagi petani, sebagai pengganti tanaman karet dan kelapa sawit. Selain itu, selama 30 bulan tanaman kurma telah berbuah. Bibit kurma yang terjamin kualitas serta produksinya, satu pohon kurma bisa memproduksi 320 kilogram buah. Bila saja dikalikan harga Kurma kualitas bagus Rp 150 ribu per $\mathrm{kg}$, maka hasilnya cukup menjanjikan dan tentunya akan meningkatkan pendapatan masyarakat. Produk-produk olahan kurma sebagian sudah sangat dikenal oleh masyarakat seperti buah kurma kering dan sari kurma. Produk-produk olahan ini memiliki citarasa yang lezat sekaligus memiliki khasiat bagi kesehatan. Menurut Retnowati dan Kusnadi (2014), kandungan buah kurma sebagian besar merupakan gula pereduksi, yaitu glukosa dan fruktosa sekitar 20-70\% (bobot kering) sehingga buah kurma mudah dicerna dan cepat 
mengganti energi tubuh yang hilang dan memiliki kandungan serat yang tinggi yang baik untuk kesehatan.

Bupati Rokan hulu periode Tahun 2011-2016, Drs. H. Achmad, M.Si., menyatakan optimis tanaman kurma akan menjadi alternatif yang menjanjikan sebagai pengganti tanaman kelapa sawit dan karet. Optimis Bupati Achmad dengan perkembangan tanaman kurma di Kabupaten Rohul karena karakteristik tanah dan suhu di Rohul sama dengan di Thailand, yang kini pengembangan tanaman kurma sudah berhasil di Negara Gajah Putih tersebut. Bukan saja karena suhu, tanah, dan karakteristik iklim yang sama dengan di Thailand, namun Rokan Hulu pada saat kepemimpinan Drs. H. Achmad, M.Si. sudah bekerjasama dengan pemilik perkebunan Kurma terbesar di Thailand, yang telah berhasil mengembangkan tanaman kurma di Thailand dan melakukan penelitian tentang kurma selama 18 tahun.

Meskipun memiliki prospek yang sangat baik, budidaya kurma bukan merupakan sesuatu yang umum dilakukan di wilayah tropis. Masyarakat Indonesia mengenal tanaman kurma sebagai tanaman khas daerah gurun pasir yang kering seperti Saudi Arabia dan sekitarnya dan meyakini bahwa kurma di Indonesia tidak akan mampu berbuah. Padahal seperti dijabarkan sebelumnya, budidaya kurma dengan bibit yang sesuai dengan iklim tropis telah terbukti berhasil dikembangkan. Sehingga diperlukan diseminasi informasi khususnya melalui sosialisasi tentang prospek budidaya kurma sebagai suatu sistem agribisnis dan tentang green constitution oleh staf pengajar Universitas Riau. Bibit kurma yang akan dikembangkan adalah bibit kurma asal Thailand yang sesuai dengan kondisi di Indonesia termasuk Kabupaten Rokan Hulu sebagai solusi untuk wilayah beriklim tropis dengan karakter yang berbeda dengan bibit kurma iklim kering seperti Timur Tengah. 
Keberhasilan penegembangan tanaman kurma tropis di Thailand diharapkan dapat memotivasi masyarakat Desa Babussalam untuk membudidayakan kurma di lahan yang telah disediakan seluas 1 hektar menjadi objek wisata terpadu religi dan agrowisata. Menurut Sutjipta (2008) di dalam Sanjaya et al. (2013), agrowisata merupakan salah satu jenis wisata yang memanfaatkan usaha pertanian (agro) menjadi suatu objek wisata. Melalui pengembangan agrowisata yang mengedepankan budaya lokal dalam memanfaatkan lahan, diharapkan dapat meningkatkan pendapatan petani sekaligus melestarikan sumber daya lahan, budaya maupun teknologi lokal yang umumnya sesuai dengan kondisi lingkungan alaminya. Maket rencana program wisata religi berupa agrowisata kurma di Kabupaten Rokan Hulu dapat dilihat pada Gambar 1.

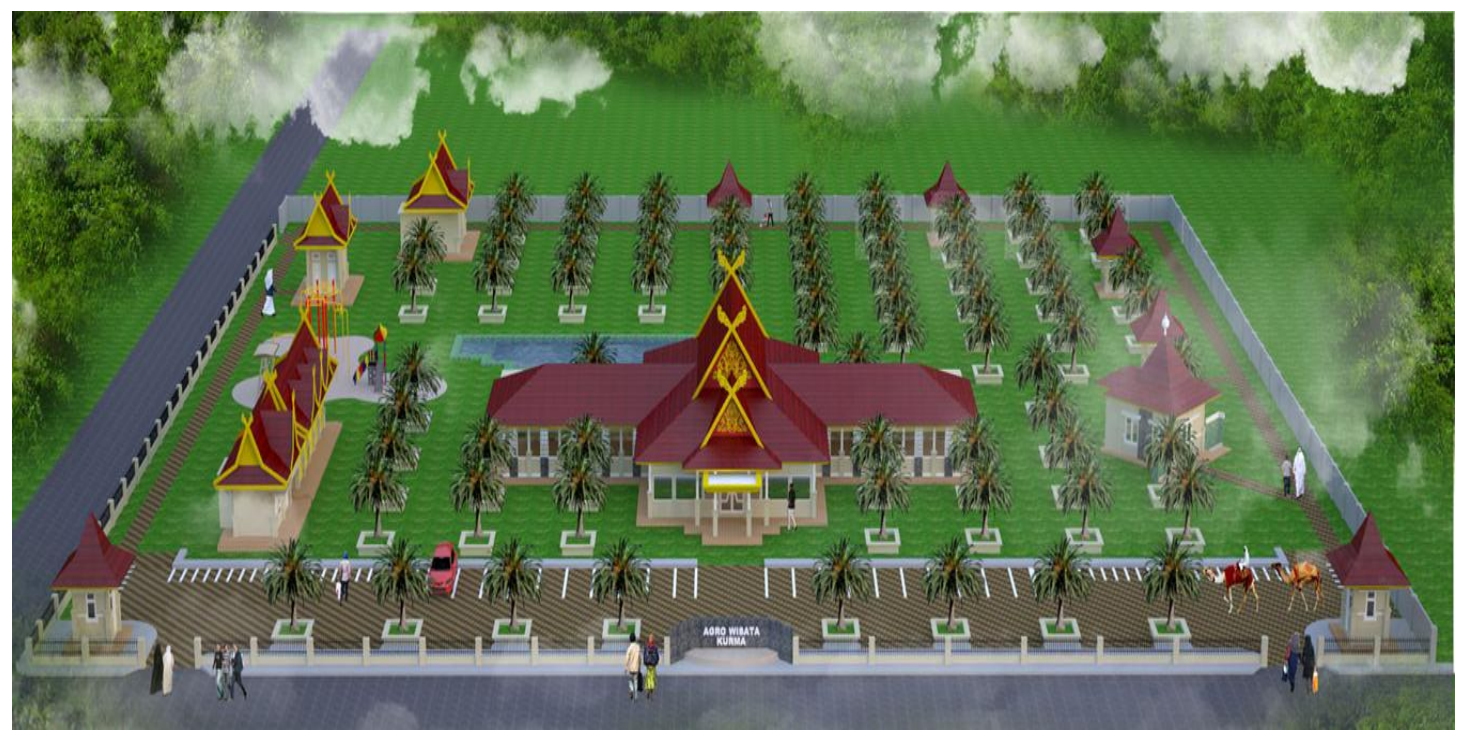

Sumber: Pemerintah Desa Babussalam (2016)

Gambar 1. Maket agrowisata kurma Desa Babussalam

\section{METODE PENELITIAN}

Desa Babussalam secara administratif masuk dalam wilayah Kecamatan Rambah Kabupaten Rokan Hulu, hal ini sesuai dengan amanah Peraturan Daerah (PERDA) Kabupaten Rokan Hulu Nomor 14 Tahun 2003 Tentang Pembentukan Desa 
Babussalam, Desa Pematang Berangan, Desa Suka Maju, Desa koto Tinggi, Desa Pekan Tebih, dan Desa Kepayang. Berdasarkan PERDA tersebut Desa Babussalam terdiri atas 3 (tiga) dusun, yaitu Dusun Nogori, Dusun Mara Tangun, dan Dusun Darussalam (pasal 3 PERDA). Adapun dasar bagi dibentuknya desa Babussalam adalah atas dasar aspirasi dan kehendak dari masyarakat, maka sesuai dengan ketentuan perundang-undangan, maka atas prakarsa dan usul dari masyarakat tersebut desa dapat dibentuk.

Rokan Hulu terkenal dengan wisata religinya yaitu wisata masjid Islamic Center Madani yang setiap minggu dikunjungi oleh ribuan pengunjung dari berbagai daerah, ini juga merupakan situasi yang dapat dianalisis, karena dengan demikian menunjukkan tingginya wisata yang datang ke Rokan Hulu, hal ini menjadi pemicu juga bagi kepala desa terpilih desa Babussalam untuk bersemangat membudidayakan kurma sebagai pengembangan wisata religi Islamic Center tersebut, hal ini sejalan dengan program Bupati terdahulu Drs. H. Achmad, M.Si. yang menggagas program Budidaya Tanaman Kurma yang bekerjasama dengan perkebunan di Thailand. Oleh karena itu, sosialisasi kepada perangkat Desa Babusaalam sebagai Desa yang memiliki program budidaya tanaman kurma, meliputi bidang pemberdayaan ekonomi dan aspek hukum melalui penyusunan peraturan desa yang berkaitan dengan program budidaya tersebut.

\section{HASIL DAN PEMBAHASAN}

\subsection{Analisis Situasi}

Berdasarkan wawancara dengan Kepala Desa terpilih Desa Babussalam Kabupaten Rokan Hulu, Bapak Basron, salah satu cara yang ditempuh dalam memacu pembangunan desa dalam rangka meningkatkan kualitas ekonomi masyarakat desa dapat dilakukan melalui cara budidaya tanaman kurma sebagai salah satu solusi sebagai 
tanaman alternatif untuk ke depan. Pengembangan tanaman kurma ini sejalan dengan apa yang telah dicanangkan oleh Bupati sebelumnya namun program ini belum sempat diaplikasikan karena terjadinya pergantian kepemimpinan.

Tanaman kurma ini akan menghasilkan dan menjadi alternatif pengganti tanaman sawit dan karet oleh masyarakat Rohul. Dengan adanya tanaman kurma, struktur tanah juga tidak rusak. Kurma merupakan tanaman yang buahnya bisa dikelola menjadi berbagai bahan makanan. Selain itu, kurma merupakan buah yang istimewa karena dari segi nutrisi, satu piring nasi sama dengan beberapa buah kurma. Kurma dikonsumsi bukan hanya di saat bulan Ramadhan saja, namun bisa dikelola menjadi puluhan jenis bahan makanan. Sehingga, ke depannya bila dikembangkan ke masyarakat maka akan jadi penghasilan yang menjanjikan bagi petani, sebagai pengganti tanaman karet dan kelapa sawit. Apalagi, selama 30 bulan tanaman kurma itu sudah berbuah. Ini perlu penelitian, perawatan khusus. Kini sudah dibentuk Komunitas Masyarakat Kurma Rohul sebagai sponsor, dan mereka nantinya yang mengembangkan tanaman kurma di daerahnya. Dengan menanam bibit kurma yang terjamin kualitas serta produksinya, satu pohon Kurma bisa memproduksi 320 kilogram buah. Bila saja dikalikan harga Kurma berkualitas tinggi Rp150 ribu per kg, maka hasilnya cukup baik dan tentunya itu akan meningkatkan pendapatan masyarakat.

Pohon kurma disebutkan di al-Quran sebagai pohon terbaik dari tanaman yang ada di bumi. Tanaman kurma menyimpan rahasia dan keistimewaan yang perlu dikaji dengan ilmu pengetahuan. Bila pohon kurma bisa tumbuh dan berbuah di Thailand yang iklimnya serta kondisi tanah sama di Rohul, tidak mustahil tanaman kurma juga bisa dibudidayakan di Negeri Seribu Suluk. Budidaya tanaman kurma akan dikembangkan tanpa menghilangkan pendapatan masyarakat yang selama ini masih bergantung pada 
sawit dan karet, namun sejauh ini mereka belum memiliki pola untuk pengelolaan tanaman kurma tersebut dalam upaya memberdayakan masyarakat, dan belum memiliki pola kebijakan karena sangat terkait dengan penggunaaan anggaran desa, untuk pengelolaan tanaman kurma ini agar dapat dibudidayakan dan mendatangkan manfaat bagi masyarakat harus diproteksi melalui aturan hukum.

Desa Babussalam telah menyediakan tanah lebih kurang 1 ha di wilayah desa Babussalam kecamatan Rambah Kabupaten Rokan Hulu, yang akan dijadikan lahan untuk budidaya tanaman kurma tersebut, namun mereka belum memiliki acuan, pedoman ataupun pola bagaimana cara mengelola tanaman kurma tersebut, maka sangat membutuhkan pembinaan dalam pengelolaaan tanaman kurma tersebut, oleh sebab itu melalui pengabdian masyarakat ini dapat dilakukan pembinaan berupa penyuluhan terkait dengan pengelolaan tanaman kurma sampai pada aturan desa atau perdes yang akan memproteksi. Menurut Salimar et al. (2009), penyuluhan dapat meningkatkan pengetahuan masyarakat dan sikap positif terhadap aspek tertentu yang menjadi target kegiatan. Maka melalui penyuluhan diharapkan implementasi budidaya tanaman kurma tersebut dapat dikelola sesuai dengan harapan, dapat meningkatkan taraf hidup masyarakat desa tersebut dan menjadi desa percontohan dalam budidaya tanaman kurma beserta dengan aturan yang mengatur pengelolaan budidaya kurma tersebut melalui peraturan desa.

\subsection{Sosialisasi Budidaya Kurma \& Green Constitution}

Kegiatan dilaksanakan dalam tiga tahapan sebagai berikut: (1) Tahap Persiapan yaitu melaksanakan observasi ke lokasi penelitian, mempersiapkan surat izin penelitian, dan mempersiapkan daftar pertanyaan wawancara untuk responden; (2) Tahap pelaksanaan 
yaitu melakukan sosialisasi dan diskusi terkait potensi pengembangan tanaman kurma dan aspek peraturan desa berbasis konstitusi hijau dan (3) Tahap Penyelesaian yaitu menganalisis data hasil kegiatan pengabdian ini dengan mengelompokkan serta menghubungkan aspek-aspek yang berkaitan, termasuk respon dan saran dari masyarakat dan aparat desa untuk persiapan laporan kegiatan.

Kegiatan sosialisasi dilaksanakan di Kantor Kepala Desa Babusalam, Pasir Pengaraian, Rokan Hulu pada tanggal 5 November 2017. Peserta sosialisasi adalah perangkat Desa Babussalam diantaranya Ketua RT/RW setempat. Pemilihan peserta kegiatan sosialisasi ini didasarkan pada peran mereka didalam masyarakat sebagai media dalam penyampaian informasi yang lebih luas kepada anggota masyarakat lainnya. Kepala Desa Babusalam, Basron, juga hadir dalam acara ini sekaligus sebagai pembuka acara. Peserta kegiatan sangat antusias untuk mengikuti acara ini karena mereka menyadari bahwa bekal pengetahuan yang meraka dapatkan nantinya akan bermanfaat untuk meningkatkan pengetahuan mereka terkait pengembangan desa yang tentunya berimbas juga kepada kesejahteraan warga.

Materi yang disampaikan yang pertama terkait dengan Green constitution, selanjutnya materi tentang Budidaya Kurma. Selanjutnya pada akhir materi, diberikan kesempatan kepada peserta kegiatan untuk diskusi dimana para peserta bebas bertanya Pemberdayaan Masyarakat Desa Babusalam Kabupaten Rokan Hulu melalui Budidaya dan Peraturan Desa yang berbasis Green Constitution. Peserta sangat antusias dengan acara ini yang tergamar dari proses tanya jawab.

Tingkat keberhasilan kegiatan sosialisasi dinilai baik berdasarkan empat indikator (Widyasanti et al., 2016) yaitu: (1) peningkatan pengetahuan tentang potensi tanaman kurma dan konsep green constitution, yang dilihat dari motivasi perangkat 
Desa untuk menyusun langkah implementasi peraturan desa; (2) minat peserta yang ditunjukkan dengan adanya keaktifan peserta selama kegiatan diskusi dengan beragamnya pertanyaan yang diajukan oleh peserta; (3) kesesuaian materi dengan kebutuhan masyarakat untuk meningkatkan pendapatan selain budidaya sawit dan karet sekaligus mendukung konsep wisata religi dan agrowisata; dan (4) faktor dampak dengan adanya dukungan kepala desa dan perangkat desa untuk mengimplementasikan kegiatan budidaya kurma setelah kegiatan sosialisasidilakukan.

\section{KESIMPULAN DAN REKOMENDASI}

Kegiatan sosialisasi budidaya tanaman kurma dan konsep Green Constitution telah berjalan dengan baik. Hal ini terlihat dari motivasi dan itikad baik dari Pihak Pemerintah Desa dalam menyiapkan perangkat dan masyarakat desa Babussalam dalam mengimplementasikan usaha budidaya tanaman kurma sebagai trademark pendukung wilayah Rokan Hulu sebagai daerah wisata yang islami dan religius ke depan.

Kegiatan sosialisasi ini perlu dilanjutkan dengan tahap penyuluhan masyarakat agar masyarakat memahami potensi yang dimiliki tanaman kurma sebagai sumber pangan andalan yang memberikan keuntungan bagi Desa Babussalam. Selain sesuai dengan konsep konstitusi hijau, budidaya kurma juga mendukung kegiatan ekonomi masyarakat melalui penguatan citra wisata religi yang saat ini semakin mendapat perhatian dari masyarakat dari dalam dan luar Kabupaten Rokan Hulu. Selain itu untuk lebih mendukung implementasi program budidaya tanaman kurma yang relatif baru dikembangkan di Indonesia sebagai daerah tropis, direkomendasikan untuk melaksanakan melakukan analisis kesesaian lahan Desa Babussalam untuk tanaman kurma, dan analisis finansial dari budidaya kurma dengan luas tanam satu hektar yang 
direncanakan. Tujuannya agar lebih tergambar secara riil keuntungan ekonomi yang akan didapatkan dengan penggunaan bibit kurma asal Thailand yang sesuai dengan iklim Indonesia. Perhitungan finansial ini juga akan memudahkan proses manajemen agroindustri dan agrowisata selanjutnya di Kabupaten Rokan Hulu.

\section{DAFTAR PUSTAKA}

Asshiddiqie, J. (2009). Green Constitution (Nuansa Hijau Undang-Undang Dasar Negara Republik Indonesia Tahun 1945). Jakarta: PT Raja Grafindo Persada.

Carson, R. (2002). Silent Spring. Anniversary edition. Boston: Houghton Mifflin Company.

Isyandi, B. \& Indarti, S. (2008). Kajian Potensi Perekonomian Kabupaten Rokan Hulu. Laporan Penelitian Fakultas Ekonomi Universitas Riau. Diunduh dari https://repository.unri.ac.id/xmlui/bitstream/handle/123456789/985/cover1.PDF?s equence $=1 \&$ is Allowed $=\mathrm{y}$

Kadir, H. \& Syapsan. (2012). Peranan Perkebunan Kelapa Sawit dalam Menyerap Tenaga Kerja di Kabupaten Rokan Hulu. Jurnal Sosial Ekonomi Pembangunan, 3(7), $24-32$.

Pemerintah Desa Babussalam. (2016). Maket agrowisata kurma Desa Babussalam. Desa Babussalam.

Retnowati, P.A. \& J. Kusnadi. (2014). Probiotic Beverages Manufacture of Date Palm Fruit (Phoenix dactylifera) Extract with Lactobacillus casei and Lactobacillus plantarum Isolate. Jurnal Pangan dan Agroindustri, 2(2),70-81. 
Salimar, S. Mulyati, A. Triwinarto \& R. Dewi. (2009). Peran Penyuluhan dengan Menggunakan Leaflet terhadap Perubahan Pengetahuan dan Sikap Ibu Balita Gizi Kurang. Jurnal PGM, 32(2), 122-130

Sanjaya, I.G.A., C.G.A. Semarajaya \& I.N.G. Astawa. (2013). Studi Potensi Subak Renon di Denpasar Selatan untuk Pengembangan Agrowisata. E-Jurnal Agroekoteknologi Tropika, 2(1), 62-70

Syahza, A. (2012). Ekonomi Pembangunan, Teori dan Kajian Empirik Pembangunan Pedesaan, edisi Revisi. Pekanbaru: Unri Press.

Septiawan, H., Hariyadi \& M. Thohari. (2014). Analysis of Environmental Management Palm Oil Mill Batu Ampar - PT SMART Tbk in the Implementation of Indonesian Sustainable Palm Oil. Jurnal Pengelolaan Sumberdaya Alam dan Lingkungan, $4(2), 136-144$

Wahyudin, D. (2016). Strategi Konsep Ekonomi Hijau sebagai Sustainable Development Goals di Indonesia. Prosiding Seminar STIAMI, 3(1), 34-45

Wahyuni, S.. I. Gunawan \& E. Bahar. (2013). Analisis Faktor Produksi yang Mempengaruhi Pendapatan Petani Karet di Desa Rambah Hilir Tengah Kecamatan Rambah Hilir Kabupaten Rokan Hulu. Jurnal Sungkai, 1(2), 37-47

Wardhono, A. (2008). Perspective of Rice Agribusiness Managerial in Jember Regency. $J-S E P, 2(3), 28-34$

Widyasanti, A.,S.H. Putri, \& S.N.P. Dwiratna. (2016). Upaya Pemberdayaan Masyarakat Melalui Pelatihan Pembuatan Produk Sabun Berbasis Komoditas Lokal di Kecamatan Sukamantri Ciamis. Dharmakarya. Jurnal Aplikasi Ipteks untuk Masyarakat, 5(1), 29 - 33 
Yusa, I.G. \& B. Hermanto. (2018). Implementasi Green Constitution di Indonesia: Jaminan Hak Konstitusional Pembangunan Lingkungan Hidup Berkelanjutan. Jurnal Konstitusi, 15(2), 206-326. 